\section{Serum cholesterol and triglyceride levels in Australian adolescent vegetarians}

Vegetarians consume a diet free of or low in animal meat but containing, in addition to vegetable products, eggs and milk and their derivatives. The diet is low in saturated fats and high in polyunsaturated fats; it is also relatively high in beans and fibre, which may actively reduce serum cholesterol. Such diets would be expected to produce blood lipid levels lower than those found in the average population, and this has been confirmed in a few studies. ${ }^{1-3}$ Such studies have not been performed on adolescents or children. We report the results of a preliminary study of blood lipid levels in 183 Seventh Day Adventist (SDA) adolescents and compare them with the results of a previous study of adolescents from the general Australian population. ${ }^{45}$

\section{Method and results}

The children, aged 12-17 years ( 89 girls and 94 boys), were from an SDA high school in a suburb of Sydney. They were fairly equally distributed in all age groups except for the highest, in which numbers were small. The children voluntarily completed a questionnaire, indicating the type of food in their regular diet and the approximate amount consumed each week. They were then divided into two groups: 78 who occasionally or regularly ate animal meat, fish, or fowl (MFF), and 105 whose protein was entirely from dairy and vegetable sources (non-MFF). Fasting serum cholesterol and triglyceride levels were estimated by means of an AutoAnalyzer. Assay methods and quality control procedures have been reported. ${ }^{45}$

The table summarises the results of this and the previous studies. ${ }^{45}$ The mean serum cholesterol level was $4 \cdot 2 \pm S D 0.73 \mathrm{mmol} / 1(161 \pm 28 \mathrm{mg}$ $100 \mathrm{ml})$ in the vegetarians and $5.2 \pm 0.83 \mathrm{mmol} / 1(199 \pm 32 \mathrm{mg} / 100 \mathrm{ml})$ in the "free-living" control group $(P<0.001)$. The difference in mean cholesterol levels between the MFF and non-MFF groups was also highly significant $(P<0.001)$.

Mean fasting serum cholesterol and triglyceride levels $( \pm S D)$ in vegetarian and free-living adolescents

\begin{tabular}{c|c|c|c}
$\begin{array}{c}\text { Adolescent } \\
\text { group }\end{array}$ & $\begin{array}{c}\text { No in } \\
\text { group }\end{array}$ & $\begin{array}{c}\text { Serum cholesterol } \\
(\mathrm{mmol} / \mathrm{l})\end{array}$ & $\begin{array}{c}\text { Serum triglyceride } \\
(\mathrm{mmol} / \mathrm{l})\end{array}$ \\
\hline Vegetarian & 183 & $\mathbf{4} \cdot 2 \pm 0.73$ & $0.76 \pm 0.36$ \\
MFF & 78 & $4.4 \pm 0.73$ & $0.78 \pm 0.36$ \\
Non-MFF & 105 & $4 \cdot 0 \pm 0.70$ & $0.73 \pm 0.36$ \\
Free-living & 1456 & $5.2 \pm 0.83$ & $0.81 \pm 0.41$
\end{tabular}

Conversion: SI to traditional units-Cholesterol: $1 \mathrm{mmol} / 1 \approx 38.6 \mathrm{mg} / 100 \mathrm{ml}$. Triglyceride: $1 \mathrm{mmol} / 1 \approx 88.5 \mathrm{mg} / 100 \mathrm{ml}$.

\section{Discussion}

The children in both studies came from a similar area of the Sydney suburbs and represented the various socioeconomic strata of Australian society. ${ }^{4}$ This study was primarily undertaken to determine whether the vegetarian diet of adolescents has a significant effect on blood lipid levels when compared with those in adolescents consuming a free diet. The vegetarian children had a significantly lower $\left(19^{\circ}{ }_{0}\right)$ mean serum cholesterol level but only a slightly lower serum triglyceride level. The mean serum cholesterol level also differed significantly with the degree of vegetarianism-that is, between the MFF and non-MFF groups. In contrast, the vegetarian diet had no effect on the fasting serum triglyceride level in normal adolescents. The dietary information provided by the questionnaire indicated that there was no difference in carbohydrate intake between the vegetarian children and normal controls.

West and Hayes, ${ }^{3}$ in a more-detailed study of vegetarian adults versus free-living people, also found that the serum cholesterol level correlated with the degree of vegetarianism, but mainly over the age of 35. Kirkeby ${ }^{1}$ found that serum cholesterol levels in vegetarians were significantly lower in the age groups studied, ranging from 18 to above 60 years of age. Walden $e^{2} \mathrm{al}^{2}$ found the adult serum cholesterol levels in SDAs to be $5-30^{\circ} \%$ lower than in the free-living population and found no striking difference in the triglyceride levels. Our results $(19 \%$ lower $)$ are consistent with these findings.

Many epidemiological studies have shown that the blood cholesterol level is influenced by the dietary lipid intake and that raised levels carry a major risk for coronary heart disease. The lower incidence and later emergence of coronary heart disease among SDA communities is consistent with these findings. The results in adolescent vegetarians compared with those in free-living Australian adolescents, of whom $12 \%$ have a serum cholesterol level of $6.2 \mathrm{mmol} / 1(240 \mathrm{mg} / 100 \mathrm{ml})^{45}$ or greater, may have implications in planning preventive programmes for coronary heart disease.

${ }^{1}$ Kirkeby, K, Acta Medica Scandinavica, 1966, 179, suppl No 443.

2 Walden, R T, et al, American fournal of Medicine, 1964, 36, 269.

3 West, R O, and Hayes, O B, American fournal of Clinical Nutrition, 1968 21, 853.

${ }^{4}$ Hickie, J B, et al, Medical fournal of Australia, 1974, 1, 825

${ }^{5}$ Hickie, J B, et al, Medical fournal of Australia, 1975, 1, 429.

Medical Professorial Unit, University of New South Wales, St Vincent's Hospital, Sydney, Australia

J RUYS, BSC, scientific officer

J B HICKIE, FRACP, FRCP, professor of medicine

\section{Cell-mediated immunity and transfer factor in Crohn's disease}

It has been debated whether or not patients with Crohn's disease have depressed cell-mediated immunity. ${ }^{12}$ We studied several patients with histologically proved Crohn's disease and confirmed depressed T-cell function. We then attempted to see whether the lymphocyte extract known as transfer factor could restore the $\mathrm{T}$-cell function in these patients.

\section{Patients, methods, and results}

Thirteen patients with histologically proved Crohn's disease who were not on steroids or immunosuppressive agents agreed to take part in the study. There were five men and eight women. Their mean age was 34 years (range 20-65 years). Lymphocytes were harvested by leukapheresis from healthy donors who gave strong positive reactions on tuberculin tests. Transfer factor was prepared from the lymphocytes by the method of Lawrence. Tuberculin tests $(1 / 1000$ purified protein derivative (PPD)) were performed before each injection of transfer factor and repeated one month later. The patients' spouses acted as controls. Induration of an area over $5 \mathrm{~mm}$ in diameter at $\mathbf{4 8}$ hours was read as positive. The phytohaemagglutinin (PHA) stimulation test was performed using a whole-blood micromethod ${ }^{4}$ Each experiment was done in sextuplicate and the uptake of ${ }^{125} \mathrm{I}$-deoxyuridine by the dividing cells measured in a gamma-counter. Results were expressed in counts per minute (cpm) per 1000 lymphocytes.

Nine of the patients were married and their spouses all gave a positive response to the tuberculin test to at least 1/1000 PPD. Only one of the 13 patients had a positive tuberculin reaction; the rest showed virtually no induration at 48 hours. The 12 patients with negative tuberculin skin.tests were each given transfer factor prepared from $3 \times 10^{9}$ lymphocytes, after which three developed a positive reaction on the tuberculin test Mean lymphocyte response to phytohaemagglutinin stimulation $( \pm S D)$ in the 13 patients was $4415 \pm 3712 \mathrm{cpm} / 1000$ lymphocytes. This was significantly lower than the results from 20 healthy adults $(10330 \pm 3210 \mathrm{cpm} / 1000$ lymphocytes; $\mathrm{P}<0.01)$. After receiving transfer factor the patients' mean response rose to $10170 \pm 5990 \mathrm{cpm} / 1000$ lymphocytes, significantly higher than before $(\mathrm{P}<0.01)$ and not significantly different from the values in healthy controls $(\mathrm{P}<0.05)$. 


\section{Discussion} T-cell function. It is interesting to note that our values for the PHA stimulation test in Crohn's disease were intermediate between normal values and the severely depressed values of Hodgkin's disease found in this laboratory $(1117 \pm 476 \mathrm{cpm} / 1000$ lymphocytes; $\mathrm{n}=6) . .^{5}$ Although patients with Hodgkin's disease have increased susceptibility to fungal and viral infections, this is not the case in Crohn's disease. The less severe depression of $\mathrm{T}$-cell function found in our patients may be related to this relative immunity to those infections. our patients had a serum albumin level under $31 \mathrm{~g} / \mathrm{l}$, and the mean level was $40.3 \mathrm{~g} / \mathrm{l}$. The mean haemoglobin level was $13.8 \mathrm{~g} / \mathrm{dl}$ with no level below $11 \cdot 1 \mathrm{~g} / \mathrm{dl}$. Folate deficiency can also cause a lowered PHA response. All our patients had normal red cell folate levels $(>160$ $\mu \mathrm{g} / \mathrm{l}$ of red cells).

We have shown a significant improvement in the response to PHA stimulation after giving transfer factor. Three of our patients also showed conversion of their tuberculin test results. One of the questions that this study raises is the significance of $\mathrm{T}$-cell abnormalities in Crohn's disease. The T-cell abnormalities may be causally linked with the disease or may just be an epiphenomenon. To resolve this question and also to study the therapeutic effect of transfer factor it wil! be necessary to carry out long-term controlled trials.

We thank Professor C Clark, Dr J Lennard-Jones, and Dr M Sarner for allowing us to study patients under their care.

${ }^{1}$ Asquith, P, Kraft, S C, and Rothberg, R M, Gastroenterology, 1973, 65, 1. 2 Neuwissen, S G M, et al, Gut, 1975, 16, 854.

3 Lawrence, H S, and Al-Askari, A, In-vitro Methods in Cell Mediated Immunity. New York, Academic Press, 1971.

${ }^{4}$ Luquetti, A, and Janossy, G, Fournal of Immunological Methods, 1976, 10, 7.

$5 \mathrm{Ng}, \mathrm{R}$ P, et al, Lancet, 1975, 2, 901.

Department of Clinical Haematology, University College Hospital Medical School, London WC1

R P NG, MRCP, senior lecturer in haematology

F R VICARY, MRCP, senior medical registrar
Our results show that patients with Crohn's disease have depressed

Malnutrition may cause abnormalities of T-cell function. None of

histochemical preparation and a high measured glycogen content with no $\alpha$-glucosidase activity. Liver biopsy was not undertaken since it would not have benefited the child. At the age of 8 months she was readmitted to hospital in a moribund state with heart failure unresponsive to treatment, and it was decided, with the fully informed consent of the parents, to attempt $7: 2: 1$ ) containing entrapped Aspergillus niger amyloglucosidase were prepared as described, ${ }^{2}$ except that strict aseptic precautions were taken to achieve a days with no obvious side effects. Fever occurred on the third day, although days of treatment, but there was no improvement in her general poor $\mathrm{min} / \mathrm{g} \approx 0.18 \mathrm{mg} / \mathrm{min} / \mathrm{g}$ ).

We thank the Wellcome Trust and the Muscular Dystrophy Group for most patients soon die from cardiac failure.

Several attempts have been made to mobilise stored glycogen in the glycogenoses by administering fungal or human $\alpha$-glucosidase, but these have yielded no clear-cut beneficial results. ${ }^{1}$ To overcome some of the problems of direct enzyme administration, liposomes (closed concentric bilayers of lipid alternating with aqueous spaces in which soluble substances can be entrapped) were proposed ${ }^{2}$ as carriers of enzymes. The localisation of intravenously administered liposomes in the liver and spleen of experimental animals has been shown, and several other therapeutic uses of liposomes ${ }^{3}$ have been proposed. We report here the use of amyloglucosidase-containing liposomes in an attempt to treat type II glycogenosis.

\section{Case report}

This girl, the second child of healthy unrelated parents, had congenital dislocation of the hip and was admitted to hospital at the age of $3 \frac{1}{2}$ months with a chest infection and feeding difficulties. She was noted to be floppy, and hepatomegaly was detected on clinical examination. Chest $x$-ray examination showed massive cardiomegaly. Muscle biopsy confirmed the diagnosis of Pompe's disease, showing a vacuolar myopathy with excess glycogen on liposome treatment.

Liposomes (lecithin, cholesterol, and phosphatidic acid in a molar ratio sterile, pyrogen-free preparation. Free enzyme was separated from entrapped by four centrifugation steps at $100000 \mathrm{~g}$ for 90 minutes. The liposomes were stored under nitrogen at $4{ }^{\circ} \mathrm{C}$ after passage through a $0.45-\mu \mathrm{m}$ millipore filter.

Liposomes were administered by daily intravenous injection over seven the child had been intermittently febrile in the previous week. Altogether $170 \mathrm{mg}$ of liposomal lipid containing $3 \mathrm{mg}$ of enzyme protein ( 32 units) was administered. The liver decreased in size considerably during the first four condition. She died from cardiac failure eight days after the start of enzyme treatment. Tissues were frozen at necropsy and stored at $-20 \mathrm{C}$. Enzyme and glycogen measurements are summarised in the table. The low postmortem enzyme levels were not surprising in view of the small amount administered. Heart and skeletal muscle glycogen levels were extremely high, $\vec{c}$ but the liver glycogen was much lower than expected in a child with type II OD glycogenosis (usually 10-12\%) and supported the clinical observations that the enzyme may have had some effect in breaking down liver glycogen and hence reducing liver size. Our results (see table) show that bile may be a is route of export of stored glycogen, as the level in the post-mortem sample was well above that in controls with no storage condition.

$\alpha$-Glucosidase and glycogen levels in various tissues at biopsy and necropsy

\begin{tabular}{|c|c|c|c|c|c|c|c|}
\hline \multirow{2}{*}{ Tissue } & & \multicolumn{3}{|c|}{$\underset{\text { (units*) }}{\alpha \text {-Glucosidase activity }}$} & \multicolumn{3}{|c|}{$\begin{array}{c}\text { Glycogen } \\
\text { ( }{ }_{0}^{\circ} \text { by weight) }\end{array}$} \\
\hline & & Biopsy & Necropsy & Normal & Biopsy & Necropsy & Normal \\
\hline $\begin{array}{l}\text { Liver .. } \\
\text { Spleen } \\
\text { Skeletal muscie } \\
\text { Cardiac muscle } \\
\text { Lymph node } \\
\text { Skin fibroblasts } \\
\text { Bile . . } \quad . .\end{array}$ & $\begin{array}{l}\ldots \\
\cdots \\
\cdots \\
\cdots \\
\cdots\end{array}$ & $U$ & $\begin{array}{c}0.02 \\
0.04 \\
\mathrm{U} \\
\mathrm{U}\end{array}$ & $\begin{array}{c}3.2 \\
0.17 \\
0.17 \\
11.9 \dagger\end{array}$ & $3 \cdot 0$ & $\begin{array}{l}7 \cdot 0 \\
6 \cdot 1 \\
1 \cdot 04_{+}^{+}\end{array}$ & $\begin{array}{l}<4 \\
<0 \cdot 2 \\
<0 \cdot 2 \\
0 \cdot 02+\end{array}$ \\
\hline
\end{tabular}

*Units $=\mu \mathrm{mol}$ glucose released from maltose $/ \mathrm{min} / \mathrm{g}$ tissue at $37^{\circ} \mathrm{C}(1 \mu \mathrm{mol}$ glucose

tumol glucose released from maltose $/ \mathrm{min} / \mathrm{mg}$ protein at $37: \mathrm{C}$ tmg glycogen $/ \mathrm{ml}$ bile.

$\mathrm{U}=$ Undetectable on assay.

\section{Discussion}

It is, unfortunately, difficult to estimate the true value of this treatment owing to the lack of biochemical data on liver glycogen before treatment began. Nevertheless, there does seem to have been $\dot{\sigma}$ some success in reducing stored liver glycogen. No reduction in muscle 3 glycogen was observed. Thus the future use of liposomes in the treatment of this condition is limited unless a way can be found of 3 directing liposomes to muscle tissue, perhaps by attaching tissuespecific antigens to the liposomal surface as attempted by Gregoriadis. ${ }^{4}$ financial support, Dr A Moosa for his help and advice, and Dr S M Tucker for referring the patient to us.

Requests for reprints should be addressed to DAT.

1 Hers, $\mathrm{H}$ E, and Barsy, $\mathrm{T}$ de, in Lysosomes and Storage Diseases, ed $\mathrm{H} \mathrm{G} \underset{\sigma}{\sigma}$

Hers and F Van Hoof, p 197. New York, Academic Press, 1973.
2 Gregoriadis, G, Leathwood, P D, and Ryman, B E, FEBS Letters, 1971, 14, 95.

${ }^{3}$ Ryman, B E, Proceedings of the 6th International Congress of Pharmacology, ed M Mattila, vol 5, p 92. Oxford, Pergamon Press, 1975.

4 Gregoriadis, G, Biochemical Society Transactions, 1975, 3, 613. School, London W6 8RF

D A TYRRELL, BSC, research student

BRENDA E E RYMAN, PHD FRIC, professor

Department of Paediatrics and Neonatal Medicine and the Jerry $\frac{\overline{ }}{=}$ W12 0HS

B R KEETON, MRCP, DOBSTRCOG, registrar in paediatrics

$\mathrm{V}$ DUBOWITZ, MD, FRCP, professor of paediatrics
Department of Blochemistry, Charing Cross Hospital Medical $\frac{\varrho}{\sigma}$ Lewis Muscle Research Centre, Hammersmith Hospital, London ? 